\title{
Ecodesign of technology for electrolytic sodium hypochlorite production for drinking water disinfection
}

\author{
Aleksandr Skryabin ${ }^{1 *}$ \\ ${ }^{1}$ Don State Technical University, Gagarin Square, 1, Rostov-on-Don, 344003, Russia
}

\begin{abstract}
. the paper deals with the variant of partial diversification of water supply facilities where the surplus of electrolytically generated hydrogen produced by electrolysis of sodium hypochlorite - water disinfectant -can be used for heating of production facilities and nearby consumers, production of conditioned water for technological needs from atmospheric precipitations, which confirms the possibility of economically expedient participation of the water supply enterprise in forming the regional market.
\end{abstract}

\section{Introduction}

According to the definition of the Organisation for Economic Co-operation and Development (OECD), the environmental goods and services sector includes a set of activities aimed at producing goods and services to prevent, minimise and eliminate harm to the environment and to reduce anthropogenic pollution from natural resources [1].

The water sector in many developed countries around the world has long enjoyed the status of an environmental services sector. This is due to the fact that its main task is the technological removal of pollutants not only from natural and waste water, but also from gas emissions, bringing them up to standard levels. Successful completion of this task clearly contributes to the reduction of the negative impact on the environment [2].

In Russia, there is virtually no such market, and current legislation has failed to create effective incentives for its development. As a result, Russia's lag in this area leads to limited economic growth potential and loss of competitive advantage.

Obviously, in the coming years the state of the operating system will become a key factor in the competitiveness of the entire country and of each Russian region separately. This is indicated by clearly demonstrated trends in the global market for the "environmental industry", including the sectors of water supply, waste management, energy efficient technologies, energy saving and ecological equipment. Specific benchmarks for progress in this area have also been established - the market for ecological goods and services is growing fivefold and thus creating up to 300,000 new jobs [3].

Diversification, which is based on targeted changes in their structure and the nomenclature of products, and active search for the latest markets, occupies a special place among the known and effective ways of reforming the activities of companies [4].

\footnotetext{
*Corresponding author: skryabin@zsro.ru
} 
In this aspect, MUE water supply companies seeking to develop new markets for their products, i.e. to diversify their activities, should focus their efforts on the introduction of resource and energy-saving water treatment technologies, including new technologies for chemical and biocidal water treatment, close monitoring of the current state of the drinking water supply market, study and implementation of best practices, and increased attention to the achievements of science and technology [5].

Decontamination of water plays a major role in creating those shortcomings. As we know, its main objective is to prevent waterborne diseases that are safe for people and the environment, economically viable and technologically feasible. Water decontamination in today's environment has become a complex problem which is hard to resolve. So it must be considered in terms of epidemiological, hygienic, environmental, economic and technological components [6].

The chemical methods currently used for water disinfection, which mainly use chlorine, are systematically replaced by low-concentration sodium hypochlorite produced at the point of consumption, which minimises environmental damage.

The electrolysis station generates hydrogen. Thus, the production of $1 \mathrm{t}$ of active (equivalent) chlorine is accompanied by the release of $27 \mathrm{~kg}$ of hydrogen. In the case of large-capacity production, the problem of its neutralisation is acute, which is associated with significant financial costs, increasing the cost of finished products - sodium hypochlorite [7].

On the other hand, hydrogen has a number of undeniable advantages, the most important of which are the following: hydrogen is an environmentally friendly fuel as its combustion product is water vapour; it has a very high value of combustion heat (four times higher than that of coal); it possesses high thermal conductivity.

The purpose of this work is to substantiate the ways of economically feasible utilization of associated hydrogen in the production of sodium hypochlorite to improve the environmental safety of the technological process as a whole, using the example of the electrolysis plant for the production of sodium hypochlorite in Rostov-on-Don.

In the air and in pure oxygen, hydrogen burns to form water (steam). That generates a lot of heat. Thus, the heat of hydrogen combustion is: the highest - $142708 \mathrm{~kJ} / \mathrm{kg}(12741$ $\left.\mathrm{kJ} / \mathrm{m}^{3}\right)$; the lowest $-120139 \mathrm{~kJ} / \mathrm{kg}\left(10726 \mathrm{~kJ} / \mathrm{m}^{3}\right)$. Hydrogen as a fuel is more than 2.5 times more efficient than methane, the main component of natural gas. In practical calculations, the combustion heat of hydrogen is assumed to be $120746 \mathrm{~kJ} / \mathrm{kg}$, as the gas often contains non-combustible impurities (water vapour, air, etc.) [8].

Different combustible gases require different amounts of air (oxygen) to burn completely. The higher the calorific value (heat of combustion) of the gas being burned, the more air is required and therefore more combustion products, i.e. waste, are produced (Table 1) [9].

Table 1. Theoretical oxygen and air consumption on combustion of simple gases and quantity of combustion products

\begin{tabular}{|c|c|c|c|c|c|c|}
\hline \multirow{2}{*}{ Gas } & \multicolumn{2}{|c|}{ Consumption, $\mathbf{~ m}^{\mathbf{3}} / \mathbf{m}^{\mathbf{3}}$} & \multicolumn{4}{|c|}{ Quantity of combustion products, $\mathbf{~}^{\mathbf{3}} / \mathbf{m}^{\mathbf{3}}$} \\
\cline { 2 - 7 } & oxygen & air & CO & $\begin{array}{c}\mathbf{H}_{\mathbf{2}} \mathbf{O} \\
\text { (water } \\
\text { vapours) }\end{array}$ & $\mathbf{N}_{\mathbf{2}}$ & total \\
\hline Hydrogen & 0.5 & 2.380 & - & 1.0 & 1.88 & 2.88 \\
\hline Methane & 2.0 & 9.520 & 1.0 & 2.0 & 7.52 & 10.52 \\
\hline Ethan & 3.5 & 16.66 & 2.0 & 3.0 & 13.16 & 18.16 \\
\hline Propane & 5.0 & 23.80 & 3.0 & 4.0 & 18.80 & 25.80 \\
\hline
\end{tabular}


The analysis of the data presented in the Table 1 shows the advantage of hydrogen as a fuel in terms of its environmental safety: no greenhouse gas such as carbon dioxide is produced by burning hydrogen at all. At the same time, burning $1 \mathrm{~m}^{3}$ of methane produces $1 \mathrm{~m}^{3}$ of $\mathrm{CO}_{2}$ or $\sim 1.96 \mathrm{~kg}$.

It should also be noted that burning hydrogen produces a relatively large amount of water vapour: per $1 \mathrm{~m}^{3}$ of hydrogen $\sim 0.8 \mathrm{~kg} \mathrm{H}_{2} \mathrm{O}$. Since water vapour during condensation is practically distilled water that does not contain, among other things, calcium and magnesium cations, which form deposits on the electrodes as $\mathrm{CaCO}_{3}, \mathrm{CuSO}_{4} \mathrm{Mg}(\mathrm{OH})_{2}$ compounds, it makes sense to use the condensate for the subsequent preparation of a $3 \%$ $\mathrm{NaCl}$ working solution. In theory, $243 \mathrm{~kg}$ of condensate can be produced per production of $1 \mathrm{t}$ of sodium hypochlorite [10].

At the existing electrolysis stations, it is recommended that the water be softened by passing through ion exchange resins (cationites) or treated with specially selected chemical reagents to obtain water of proper quality. These operations are also costly, and there is also the generation of waste with a disposal issue.

One possible way of using the hydrogen generated by the electrolysis of the $\mathrm{NaClO}$ solution is to obtain hot water for the company's needs [11].

A calculation of the amount of hot water $m_{\mathrm{H}_{2} \mathrm{O}}$ that can be obtained using the hydrogen generated by the electrolysis plant, for example, with a capacity of $365 \mathrm{t}$ of sodium hypochlorite per year, is provided.

Input calculation data:

- hydrogen is produced in an amount of $27 \mathrm{~kg}$ per $1 \mathrm{t}$ of sodium hypochlorite;

- heat of hydrogen combustion - $120,746 \mathrm{~kJ} / \mathrm{kg}$;

- initial water temperature $t_{H}=10^{\circ} \mathrm{C}$;

- terminal water temperature $t_{\kappa}=70^{\circ} \mathrm{C}$;

- water heat capacity: $C_{\mathrm{H}_{2} \mathrm{O}}-4.18 \mathrm{~kJ} /(\mathrm{kg} \cdot \mathrm{deg}$.);

- heat loss to the environment $-20 \%$.

1. Amount of hydrogen produced at the enterprise per year:

$$
m_{H_{2}}=0.027 \cdot 365=9.855 \mathrm{t}
$$

which is calculated on the basis of $1 \mathrm{~h}$ of work:

$$
m_{H_{2}}=9.855 / 8760=1.125 \mathrm{~kg} .
$$

2. Heat generated by the combustion of $\mathrm{H}_{2}$ :

$$
Q_{T}=1.125 \cdot 120746=135839 \mathrm{~kJ} / \mathrm{h} .
$$

3. Heat used to heat water (including losses):

$$
Q_{p}=135839 \cdot(1-0,2)=108671 \mathrm{~kJ} / \mathrm{h} \text {. }
$$

4. The amount of water heated from 10 to $70^{\circ} \mathrm{C}$ by the heat of combustion of hydrogen using the formula [3]:

$$
Q_{p}=m_{H_{2} O} \cdot C_{H_{2} \mathrm{O}} \cdot\left(t_{k}-t_{H}\right)
$$

for which we will substitute the relevant data: 


$$
108671=m_{\mathrm{H}_{2} \mathrm{O}} \cdot 4.18 \cdot\left(70^{\circ}-10^{\circ}\right)
$$

and we have $m_{\mathrm{H}_{2} \mathrm{O}}=433 \mathrm{~kg} / \mathrm{h}$.

Thus, at a given capacity of the electrolysis plant, $433 \mathrm{~kg}$ of water with a temperature of $70^{\circ} \mathrm{C}$ can be produced within an hour.

It is not difficult to calculate that the use of the associated hydrogen for these purposes will produce $\sim 10 \mathrm{~kg} / \mathrm{h}$ of hot water $\left(70{ }^{\circ} \mathrm{C}\right)$ for each kilogram of sodium hypochlorite produced at the electrolysis plant.

The hot water received can be used to heat the premises during the heating season (15 October to 15 April), i.e. for six months. Such use of hydrogen will reduce natural gas consumption within one hour.

$$
101900: 34300=2.97 \mathrm{~m}^{3},
$$

where 34300 is the heat of combustion of $1 \mathrm{~m}^{3}$ of natural gas, $\mathrm{kJ}$.

During the entire heating season, natural gas savings will be made:

$$
V_{\text {gas }}=2.97 \cdot 6 \cdot 30 \cdot 24 \approx 12834 \mathrm{~m}^{3} .
$$

Based on a natural gas price of $\sim 9.5 \mathrm{RUB} / \mathrm{m}^{3}$, the savings in cash equivalent will be:

$$
S=12834 \cdot 9.5 \approx 122 \text { thous. RUB/year. }
$$

Given that hydrogen is by a wide margin lighter than air, we believe it would be wise to install a hot water boiler on the roof of a production building from where the hot water will flow by gravity into the radiators of the heating system [12].

Another application of the hydrogen released in the electrolysis process is the use of its combustion heat to heat the process water intended for the preparation of salt solution [13].

Another application of the calorific value of hydrogen can be proposed - obtaining the hot water for subsequent use in greenhouses. The implementation of this offer is particularly promising at large electrolysis stations.

At the present time, an electrolysis station with a capacity of $7 \mathrm{t}$ of sodium hypochlorite/day or $290 \mathrm{~kg} / \mathrm{h}$ was built at Aleksandrovsky WTS, Rostov-on-Don. The utilisation of the combustion heat of the hydrogen released in this process will produce $3.0 \mathrm{t} / \mathrm{h}$ of hot water, which is enough for the operation of a large greenhouse. The opportunity to grow year-round vegetables and other products at an affordable price is one of the elements for the socially and environmentally oriented diversification of the municipal water supply company.

Natural soft water resources such as rainwater and melt water can be used to reduce water treatment costs. These waters are known to be very soft: they contain calcium and magnesium ions $\leq 1 \mathrm{mg}$-eqv/l [14].

As is known, the average annual rainfall in the Rostov region is $454 \mathrm{~mm}$, and the average annual temperature is $\sim 8{ }^{\circ} \mathrm{C}$. There is no frost for 8 months and therefore rainfall at this time can be quantified: $454: 12 \approx 303 \mathrm{~mm}$.

Water can be collected from a catchment area, for example, of $4000 \mathrm{~m}^{2}$ (this could be the roofs of an office building and a production building, and a specially prepared site)

$$
m_{\mathrm{H}_{2} \mathrm{O}}=0.303 \cdot 4000 \approx 12000 \mathrm{M}^{3} .
$$

Another reservoir of the process water is snow, which is accumulated in large quantities in Rostov-on-Don. 
For any city located in an area with snowy winters, cleaning up the streets from heavy snowfall is a time-consuming and complex operation. However, the main difficulties of winter cleaning are that snow removal to landfills requires vehicles and snow loaders, as well as a large number of maintenance personnel.

Meanwhile, fresh snowfall after melting is pure fresh water with minimal hardness salts, i.e. essentially distilled water. This is exactly the kind of water that is needed to prepare a $3 \% \mathrm{NaCl}$ solution for electrolysis.

A promising method of snow removal is the use of high-performance snow melters, whose operation is based on the use of so-called immersion burners. In such devices, the material that is liquefied or heated (snow) comes into direct contact with the flow of hightemperature gaseous combustion products (liquid or gaseous), thus achieving a high coefficient of heat utilization (up to 95-98\%) [15].

We will calculate the productivity of snow melt water running on hydrogen electrolysis waste.

Input calculation data:

1. The heat of hydrogen combustion is $120.746 \mathrm{~kJ} / \mathrm{kg}$.

2. The amount of hydrogen produced is $1.125 \mathrm{~kg} / \mathrm{h}$.

3. Ice melting heat (phase transition) $Q_{T}=6 \mathrm{~kJ} / \mathrm{mol}=333 \mathrm{~kJ} / \mathrm{kg}$.

4. Water heat capacity $C_{\mathrm{H}_{2} \mathrm{O}}=4.18 \mathrm{~kJ} /(\mathrm{mol} \cdot \mathrm{deg}$.).

5. Temperature of melt water received $-10^{\circ} \mathrm{C}$.

6. Heat loss - $20 \%$.

The calculations are performed per $1 \mathrm{~kg}$ of snow.

1. Heat consumption for snow melting:

$$
Q_{1}=1 \mathrm{~kg} \cdot 333 \mathrm{~kJ} / \mathrm{kg}=333 \mathrm{~kJ} .
$$

2. Heat consumption for heating the resulting melt water:

$$
Q_{2}=1 \cdot 4.18 \cdot 10=41.8 \mathrm{~kJ} / \mathrm{kg}
$$

3. Total heat consumption:

$$
Q_{1+2}=333+41.8=374.8 \mathrm{~kJ} / \mathrm{kg} .
$$

4. Combustion heat $1.125 \mathrm{~N}_{2}, \mathrm{~kg} / \mathrm{h}$ :

$$
Q_{H_{2}}=1.125 \cdot 120746=135839 \mathrm{~kJ} / \mathrm{h}
$$

5. Heat used for snow melting (including losses):

$$
Q_{H_{2}}^{\prime}=135839 \cdot(1-0,2)=108671 \mathrm{~kJ} / \mathrm{h} \text {. }
$$

6. The amount of snow that is melted during 1 hour:

$$
m_{c}=108671: 374.8=290 \mathrm{~kg} \text {. }
$$

Thus, using the heat of associated hydrogen combustion, it is possible to use melt water as process water and to quickly clear the water supply area from the snow. 


\section{Conclusions}

1. The effective reform of water supply facilities requires diversification, which is based on targeted application in their structure and the range of products manufactured.

2. The focus on the new markets and their successful development gives the company sustainability and increases its competitiveness in environmentally friendly technological processes aimed at reducing pollution and recycling of production waste.

3. The introduction of resource and energy-saving technologies based on the utilization of electrolytic hydrogen, a by-product of the sodium hypochlorite production improves the operating system of water supply facilities, creates an additional source of heat and reduces the cost of the main technological process.

\section{References}

1. S. El-Ghzizel, H. Zeggar, M. Tahaikt, F. Tiyal, A. Elmidaoui, M. Taky, Journal of Water Process Engineering 36 (2020)

2. D. Goodarzi, S. Abolfathi, Sina Borzooei, Journal of Water Process Engineering 37 (2020)

3. R. Cheswick, G. Moore, A. Nocker, F. Hassard, B. Jefferson, P. Jarvis, Environmental Technology \& Innovation 19 (2020)

4. X. Chen, Y. Wang, W. Li, Z. Ding, Y. Lu, J. Ding, J. Zhang, W. Qi, W. Wei, X. Zhao, Journal of Cleaner Production 265 (2020)

5. M. I. Gil, F. López-Gálvez, S. Andújar, M. Moreno, A. Allende, Food Control 100, 46-52 (2019)

6. Y. Jin, Y. Shi, R. Chen, X. Chen, X. Zheng, Y. Liu, Chemosphere, 215, 380-387 (2019)

7. A. R. Rahmani, M. R. Samarghandi, D. Nematollahi, F. Zamani, Journal of Environmental Chemical Engineering 7(1) (2019)

8. S. Ghasemian, B. Asadishad, S. Omanovic, N. Tufenkji, Water Research 126, 299-307 (2017)

9. D. Powell, A. Ebrahimi, S. Nourbakhsh, M. Meshkahaldini, A.M. Bilton, Renewable Energy 123, 590-602 (2018)

10. C.E. Schaefer, C. Andaya, A. Urtiaga, Chemical Engineering Journal, 264, 411-416 (2015)

11. F. López-Gálvez, G. D. Posada-Izquierdo, M. V. Selma, F. Pérez-Rodríguez, J. Gobet, M. I. Gil, A. Allende, Food Microbiology 30(1), 146-156 (2012)

12. N. Martynov, et al., Journal of Physics: Conference Series. 1614, 012060 (2020) doi: 10.1088/1742-6596/1614/1/012060

13. M.J. Plewa, E.D. Wagner, Encyclopedia of Environmental Health (Second Edition) 559-566 (2019)

14. M. Yang, H.K. Liberatore, X. Zhang, Current Opinion in Environmental Science \& Health, 7, 98-107 (2019)

15. N. Pichel, M. Vivar, M. Fuentes, Chemosphere 218, 1014-1030 (2019) 